\title{
DEGRADATION OF WATER PROTECTION FUNCTION OF THE WESTERN CAUCASUS MOUNTAIN OAKERIES AS A RESULT OF FELLINGS
}

\author{
Nikolay A. Bitukov ${ }^{1}$, Lev M. Shagarov ${ }^{2}$ \\ ${ }^{1}$ Sochi National Park, Russia \\ e-mail:nikbit@mail.ru \\ ${ }^{2}$ Natural Ornithological Park in the Imeretinskaya Lowland, Russia \\ e-mail:lev049@mail.ru
}

Received: 20.12.2016

\begin{abstract}
The article analyses the effect of fellings for primary use on the disturbance of the water protection function of sessile oak (Quercus petraea) forests in the Western Caucasus. The study is based on long-term monitoring of spring runoff in catchments with experimental fellings in the Forest and Hydrological Station «Gorsky» (Tuapse District, Krasnodarsky Krai). It has been established that over a 28-year period after the experimental fellings, the stabilisation of runoff conditions has never come. The runoff in oak forests is mostly impacted by clear-cuttings with tractor harvesting technology. Over 30 years after clear-cutting, the spring runoff has increased on an average by 1.46 times, with a maximum increase (by 2.5 times) being observed for the first two years after cutting. In areas with group fellings, the runoff regime is generally similar to that of the control catchment for the same period.
\end{abstract}

Key words: Black Sea coast, experimental cuttings, floods, mountain forests, Quercus petraea, slope runoff.

\section{Introduction}

The mountain forests of the Northwest Caucasus occupy an area of about $6500 \mathrm{~km}^{2}$ and are the main component of natural ecosystems in the area. They are keeping the stability of the landscape, ecological balance and hydrological regime in the region. At the same time, $53 \%$ of the area covered by forests is occupied by oakeries, among which the formation of the sessile oak Quercus petraea (Matt) Liebl. dominates (Polezhaj, 2011).

Of all the anthropogenic facts, the greatest impact on the state of mountain forests and their ecological potential is made by fellings for primary use, resulting in substantial disturbance of the hydrological regime, intensive development of erosion, and changes in the qualitative structure of the new forest generation. Therefore, the water regime of mountain forest ecosystems in connection with fellings is of great importance for the development of a sustainable forest management strategy in the region (Koval \& Bitukov 1972, 2001; Bitukov, 1981, 1988, 1996a, 1996b, 2007, 2011; Bitukov et al., 2011, 2012; Koval et al., 2012; Shagarov, 2012, 2013; Bitukov \& Shagarov, 2013a, 2013b).

Over the past 60 years, both the average daily precipitation intensity and extreme precipitation have increased in many regions (Groisman et al., 2005; Donat et al., 2013; Seneviratne et al., 2012).
Part of these changes, or even individual events (Pall et al., 2011; Herring et al., 2014), have been attributed to climate change (Zhang et al., 2007; Min et al., 2011). In the Black Sea region, the potential for extreme summertime convective precipitation has grown (Dee et al., 2011); besides, the substantial sea surface temperature has increased. A particularly devastating convective event in the study area was the extreme precipitation near the town of Krymsk in July 2012 (Kotlyakov et al., 2013). Carrying out ensemble sensitivity simulations with a convection-permitting atmospheric model has shown the crucial role of the increase of the sea surface temperature in the extremeness of that event (Meredith et al., 2015). We have also analysed the long-term data from weather stations «Aibga» and «Gorsky» in the Sochi national park and compared it with the data from reference weather stations of The Federal Service for Hydrometeorology and Environmental Monitoring of Russia (Roshydromet) in the region and found an increase of the air temperature and precipitation in the mountain forests of the Western Caucasus (Pestereva et al., 2012; Bitukov \& Shagarov, 2013). Under an initially mild capacity of the Western Caucasus mountain oakeries to regulate water, a negative impact of fellings reflected in reduced ability to regulate extreme rainfalls. 


\section{Material and Methods}

PROFILE OF THE STUDY AREA. According to climate conditions, the study area belongs to the North Black Sea sub-subtropical area. It occupies both the lowland and the upland of the Black Sea coast of the Caucasus between the cities of Tuapse and Anapa. The annual rainfall totals count 1541.7 $\mathrm{mm}$. The proportion of rainy days per year runs to $15-24 \%$ (56-88 days). The average annual temperature is $11.4^{\circ} \mathrm{C}$; the average temperature over a vegetation period is $16.7^{\circ} \mathrm{C}$. The warmest month is July (average temperature $22.8^{\circ} \mathrm{C}$ ), the coldest one is January (average temperature $-1.4^{\circ} \mathrm{C}$ ). The highest attainable temperature is $28^{\circ} \mathrm{C}$, the lowest $-16^{\circ} \mathrm{C}$. The relative humidity varies between $70-80 \%$ throughout a year.

In 1972, in the territory of the former Dzhubga mechanised leskhoz (logging company) in the basin of the river Dzhubga (the basin of the brook Chernovolova Shel) within ten $\mathrm{km}$ from the coast, the forest and hydrological station (FHS) «Gorsky» was laid down to explore the ecological functions of Quercus petraea plantations. The effect of clear felling and two-stage group felling on two water catchment areas was studied at the station, and the other two water catchment areas were left as the control ones. The FHS «Gorsky» is representative for forest growth, geological, soil and climate conditions for the formation of the sessile oak. The area, where the station is located, is part of the Northwestern Greater Caucasus Mountain Range and characterised by low-mountain heavily eroded relief in a north-western exposure, consisting of 4 watersheds sizing from 0.06 to $0.249 \mathrm{~km}^{2}$ at altitudes 40-287 $\mathrm{m}$ above the sea level (Fig. 1).

The hydro-geological conditions of the station are determined by the absence of reservoir horizons, the presence of water marking the thickness of the fractured bedrock and groundwater of the coating quaternary loams. According to the soil particle size analysis, the sandy particle volume of soil varies from 7 to $40 \%$, the silt particle - from 7 to $27 \%$, the clay particle - from 40 to $60 \%$; soil specific gravity $-2.7 \mathrm{~g} / \mathrm{cm}^{3}$. The soils are brown mountain forest, for the major part they are shallow. The depth of soil, depending on the steepness of the slopes, varies from $10-20 \mathrm{~cm}$ up to $100 \mathrm{~cm}$ or more. Studies of water-physical characteristics undertaken in the FHS «Gorsky» has shown that these soils are characterised by high rates of absorption in the upper horizons (up to $1.5 \mathrm{~mm} / \mathrm{min}$ ) and a relative confining layer at a depth of 60-70 cm. The volume weight of soil along the profile varies from $1.08 \mathrm{~g} / \mathrm{cm}^{3}$ in the horizon $1-11 \mathrm{~cm}$ to $1.66 \mathrm{~g} / \mathrm{cm}^{3}$ at a depth of $70-80$ cm (Bitukov et al., 2012).

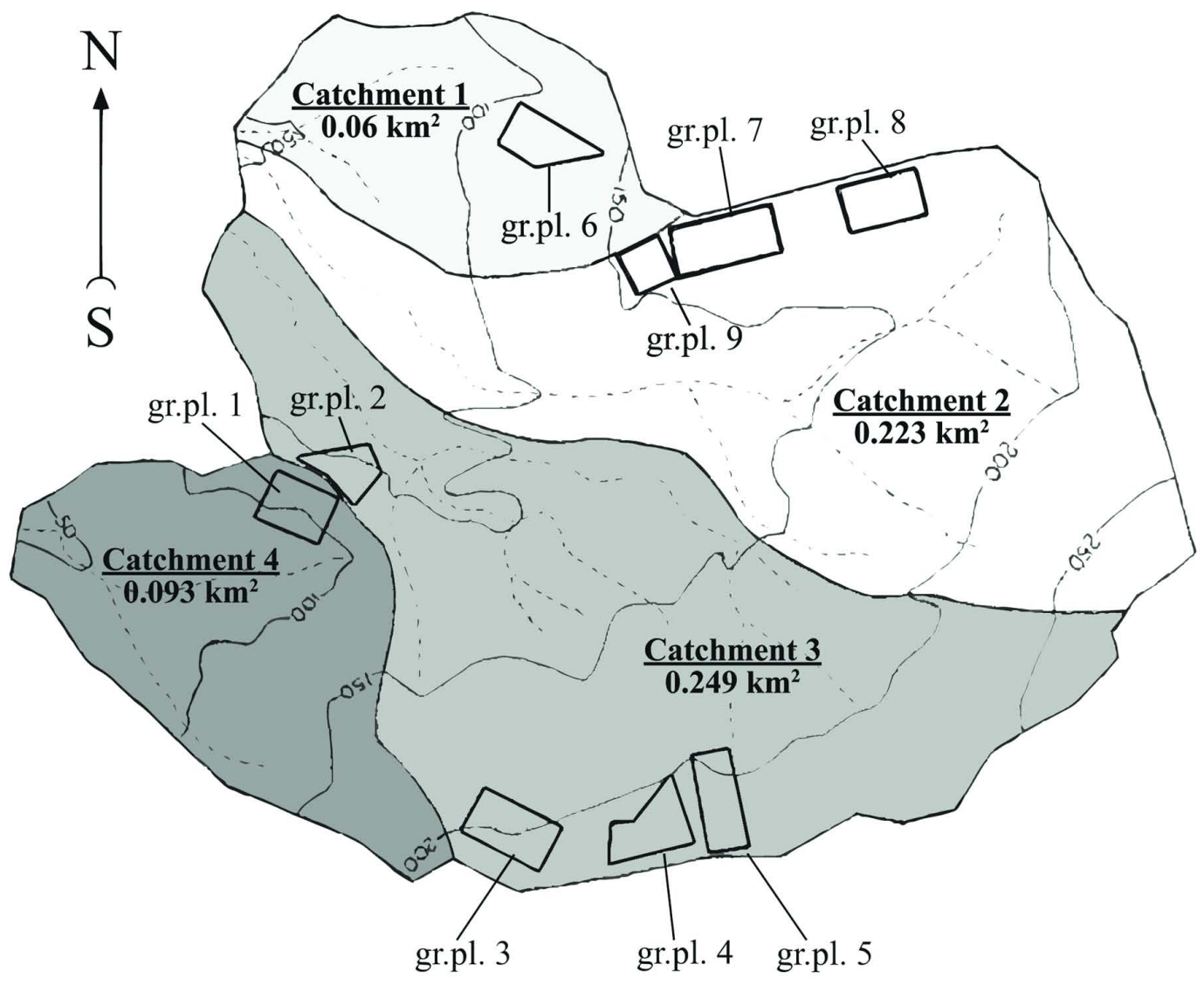

Fig. 1. Location of catchments and growth plots in the forest and hydrological station «Gorsky» in square 30, Dzhubga's local forestry laid down in 1972-1974; gr.pl. - growth plot. 
FORESTRY-BASED IMPACTS. All catchments of the station had been completely forested before felling. Plantings are presented by pure oak (Quercus petraea) and oak-hornbeam (Quercus petraea-Carpinus betulus L. - Carpinus orientalis Mill.) forest stands with an admixture of oriental beech (Fagus orientalis Lipsky), yellow-paint maple (Acer pictum Thunb.) and wild service tree (Sorbus torminalis (L.) Crantz). The canopy closure is $0.5-0.7$; the growth class is III-V.

The territory of the station was partly $(10-15 \%$ of the area) worked (passed) by voluntary-selective cutting in 1963 in the most convenient locations for timber harvest and export (with the pick (selection) $10-12 \%$ of standing volume), which helped to reduce the overall completeness to 0.7 and to increase the number of trees of vegetative origin in the composition of plantations.

In catchment 1 in 1981-1982 a clear-cutting in an area of $0.0404 \mathrm{~km}^{2}(67.3 \%$ of the catchment area) was held. The rest of the basin $\left(0.0196 \mathrm{~km}^{2}\right)$, due to the measurable steepness of slopes (more than $30^{\circ}$ ) and the location of the thalweg streams, remained not felled. In catchment 2 a first group gradual two-stage felling in an area of $0.0392 \mathrm{~km}^{2}$ was made in 1982-1983, and in 1988-1989 - a second felling in an area of $0.023 \mathrm{~km}^{2}$, which totals $27.9 \%$ of the catchment area. Morphometric and forest mensuration characteristics of catchments in the FHS «Gorsky» before felling are shown in Table 1.

To study the dynamics of growth and development of forest stands in the station catchments in 1972, growth plots (gr.pl.) were laid out. In catchment 1 - gr. pl.6 (oakery hornbeam: Quercus petraea \& Carpinus orientalis dominate); in catchment 2 - gr.pl.7 (oakery grasses: Quercus petraea dominates) and gr.pl.8 (oakery azalea: Quercus petraea \& Rhododendron luteum Sweet dominate); in catchment 3 - gr.pl.2 (oakery azalea: Quercus petraea \& Rhododendron luteum dominate), gr.pl.3 (oakery hornbeam: Quercus petraea \& Carpinus betulus dominate), gr.pl.4 (oakery hornbeam: Quercus petraea \& Carpinus betulus dominate), gr.pl.5 (oakery hornbeam: Quercus petraea \& Carpinus betulus dominate); in catchment 4 - gr.pl.1 (oakery hornbeam: Quercus petraea \& Carpinus orientalis dominate).

Table 1. Morphometric and forest mensuration characteristics of catchments in the forest and hydrological station «Gorsky» before felling

\begin{tabular}{|c|c|c|c|c|}
\hline \multirow{2}{*}{$\begin{array}{l}\text { Morphometric and forest mensuration } \\
\text { characteristics }\end{array}$} & \multicolumn{4}{|c|}{ Catchment forest and hydrological station «Gorsky» } \\
\hline & 1 & 2 & 3 & 4 \\
\hline Area, $\mathrm{km}^{2}$ & 0.06 & 0.223 & 0.249 & 0.093 \\
\hline Elevation difference, in $\mathrm{m}$ & 119 & 234 & 223 & 172 \\
\hline Average slope, in degrees ${ }^{\circ}$ & 17.5 & 13.2 & 13.3 & 19.0 \\
\hline Length of the catchment, in $\mathrm{m}$ & 380 & 1000 & 940 & 500 \\
\hline Average width of the catchment, in $\mathrm{m}$ & 190 & 228 & 245 & 186 \\
\hline Direction of slopes & $\begin{array}{c}\text { northwest } \\
\text { west }\end{array}$ & northwest & $\begin{array}{c}\text { north } \\
\text { northwest }\end{array}$ & $\begin{array}{c}\text { northwest, } \\
\text { southwest }\end{array}$ \\
\hline Composition of plants & $8 \mathrm{SO} 1 \mathrm{OB} 1 \mathrm{OH}$ & $7 \mathrm{SO} 2 \mathrm{OB} 1 \mathrm{OH}$ & $5 \mathrm{SO} 3 \mathrm{OB} 2 \mathrm{OH}$ & $6 \mathrm{SO} 3 \mathrm{OH} 1 \mathrm{OB}$ \\
\hline Average height, in $\mathrm{m}$ & 18.5 & 19.9 & 20.8 & 21.7 \\
\hline Average diameter, in $\mathrm{cm}$ & 29.6 & 28.6 & 26.7 & 32.2 \\
\hline Forest cover percent, in $\%$ & 100 & 100 & 100 & 100 \\
\hline Age class & $\mathrm{V}-\mathrm{VI}$ & $\mathrm{V}-\mathrm{VI}$ & $\mathrm{V}-\mathrm{VI}$ & $\mathrm{V}-\mathrm{VI}$ \\
\hline Growth class & VI.0 & III.9 & III.2 & III.4 \\
\hline Forest density & 0.7 & 0.7 & 0.7 & 0.7 \\
\hline Wood volume, $\mathrm{m}^{3}$ per $1 \mathrm{~km}^{2}$ & 19200 & 16900 & 17800 & 20300 \\
\hline Years of logging & $1981-1982$ & $\begin{array}{l}1982-1983 \\
1988-1989 \\
\end{array}$ & No logging & No logging \\
\hline Cutting method & $\begin{array}{l}\text { Clear- } \\
\text { felling }\end{array}$ & $\begin{array}{l}\text { Group-felling } \\
\text { Two stage }\end{array}$ & Control & Control \\
\hline Felling, in $\mathrm{km}^{2}$ & 0.0404 & $\begin{array}{l}0.0392 \\
0.0230 \\
\end{array}$ & 0 & 0 \\
\hline Felling, $\%$ of catchment area & 67.3 & $\begin{array}{l}17.6 \\
10.3\end{array}$ & 0 & 0 \\
\hline
\end{tabular}

Note: SO - sessile oak (Quercus petraea), OB - oriental beech (Fagus orientalis), OH - oriental hornbeam (Carpinus orientalis). 
In gr.pl.6 clear-cutting of 1981-1982 was tested; in gr.pl.7 and gr.pl.8 a first group felling of 1982-1983; in gr.pl.9 a second group felling of 1988-1989.

The location of growth plots in the HFS «Gorsky» is shown in Fig. 1.

METHODS OF HYDROMETRIC RESEARCH. A slope runoff in the mountains, consisting of surface and subsurface runoff, is formed due to the excess of rainfall intensity over the minimum soaking. The runoff observation in the mountain experimental catchments meant choosing the right place to install channel control, to select and calculate the appropriate type of recording post, to construct and install facilities and equipment for runoff recording. Our experience has shown that for the streams with a maximum water flow rate up to $1.5 \mathrm{~m}^{3} / \mathrm{s}$ the best option is constructing a thinwalled concrete weir with a triangular cut (an angle of the cutout $45^{\circ}$ or $90^{\circ}$ ). Calibration curves for these weirs coincide with the theoretical ones and fairly stable over time (Bitukov, 1981).

Conventional methods of field microclimate, water-balance, and forestry and taxation research were used for monitoring. A statistical method for correlative analysis was used, as well as methods of comparative geographical and spatiotemporal analyses. Computer programs as Microsoft Access, Microsoft Excel, StatSoft STATISTICA were used for data processing.

\section{Results and Discussion}

Theoretical and experimental studies have revealed a link between microclimate and silvicultural indexes over a long-term observation period for areas with experimental felling and control areas (Koval \& Bitukov, 2001; Shagarov, 2013). Moreover, it can be considered a proven ability to assess changes of slope runoff based on a change of the climatic characteristics in various forest stands and characteristics of the underlying surface (mainly of ground vegetation and soil covering). It has been observed that, on the one hand, the slope runoff is formed in a very dynamic environment as in the time frame and on the genesis, and, on the other hand, it determines the water balance and the mode of its components in the areas of different scopes, from micro grounds to main rivers basins in the region (Shagarov, 2012).

A streamflow or channel runoff in all catchments in the FHS «Gorsky» can be fully attributed to slope runoff because the duration of floods are low, and in a dry season all the streams dry up.
With the difference in squares of the smallest and largest catchments by four times, the average annual runoff before felling for catchment 1 was $795 \mathrm{~mm}$, for catchment 2-708 mm, for catchment 3-745 mm, and for catchment 4-753 mm, which makes $46-52 \%$ of the precipitation. The bulk of the annual runoff is made by a runoff over the cold season, although summer floods are more intense and exceed in volume that of in autumn and winter.

In all catchments a 7-year calibration cycle of geo-ecological researches has been carried out to establish a mathematical relation between the control and the experimental basins. Thus, for the pair of stream catchments 1 and 4 (the control one), statistical important correlations between the monthly amount of the runoff $(H, \mathrm{~mm}$ of layer) were observed:

- $\quad$ catchment 1 with clear-cutting of $H_{1}$ and catchment 4 (the control one) of $H_{4}$ :

- $\quad$ over the cold period $H_{1}=0.880 \times H_{4}$...at $R^{2}=0.932$

- $\quad$ over the warm period $H_{1}=0.822 \times H_{4} \ldots$ at $R^{2}=0.959$;

- $\quad$ for a pair of the 2nd and 3rd catchments:

- $\quad$ catchment 2 with group felling of $\mathrm{H}_{2}$ and catchment 3 (the control one) of $H_{3}$ :

- $\quad$ over the cold period $H_{2}=1.032 \times H_{3} \ldots$ at $R^{2}=0.940$

- $\quad$ over the warm period $\mathrm{H}_{2}=0.944 \times H_{3} \ldots$ at $R^{2}=0.963$.

Using these data dependency observations on the control catchments, the calculated runoff amount $H_{\text {calc }}$ in the experimental catchments was obtained and compared with the observed runoff amount $H_{\text {obs }}$. This way the natural runoff dynamics in the course of time has been considered. The resulting indexes of the streamflow change in catchments with experimental felling $K_{\text {change }}=H_{o b s} \times H_{\text {calc }}{ }^{-1}$ were analysed over the period of 30 years after felling.

For a long period here, the maximum monthly runoff modules have changed on average from 8.1 to $15.3 \mathrm{l} / \mathrm{s}$ per $10,000 \mathrm{~m}^{2}$, i.e. their numbers are by 8-14 times higher than in the beech forest zone. The maximum annual runoff modules are also very high - in some years they reached $49 \mathrm{l} / \mathrm{s}$ per 10,000 $\mathrm{m}^{2}$. The depth of soil profile that is able to quickly absorb the rainfall in the oak forests is 3 times less than in the beech forest zone. The mountain slopes under oak forests in the region cannot handle the water showers by drainage, only when their intensity is more than $0.1 \mathrm{~mm} / \mathrm{min}$ and the amount of rainfall is over $30 \mathrm{~mm}$ (Koval \& Bitukov, 2001). 
After the experimental felling in the sessile oak formation in small (elementary) catchments with continuous felling, the maximum runoff increase (by 2.5 times) was observed in the $3^{\text {rd }}$ $-5^{\text {th }}$ year after felling (Fig. 2, 3). The average runoff in the catchment with clear-cutting has increased by 1.46 times; a maximum increase by 2.5 times was observed over the first 2 years after felling (Fig. 2). At the same time, there are differences in regulating a runoff in the cold and warm seasons due to the balance characteristics of each of them.

In the catchment with group felling, a runoff increase by 1.1 times has been observed for about 15 years after felling. The trend of the indexes of runoff change in catchment 2 with group felling has been slowly approaching 1 for 29 years after felling (Fig. 3), the infiltration part of the water balance has been 3 times less than in the control catchment. Penetration of moisture into the deeper soil horizons decreases to $65 \mathrm{~mm}$ per year due to an increase of the rapid slope runoff (at an annual amount of precipitation of $1300-1700 \mathrm{~mm})$. Thus, large volumes and coefficients of floods runoff averaging about half of the precipitation are common here. In the cold season, the bulk of the floods has got runoff coefficients equal to $90-98 \%$.

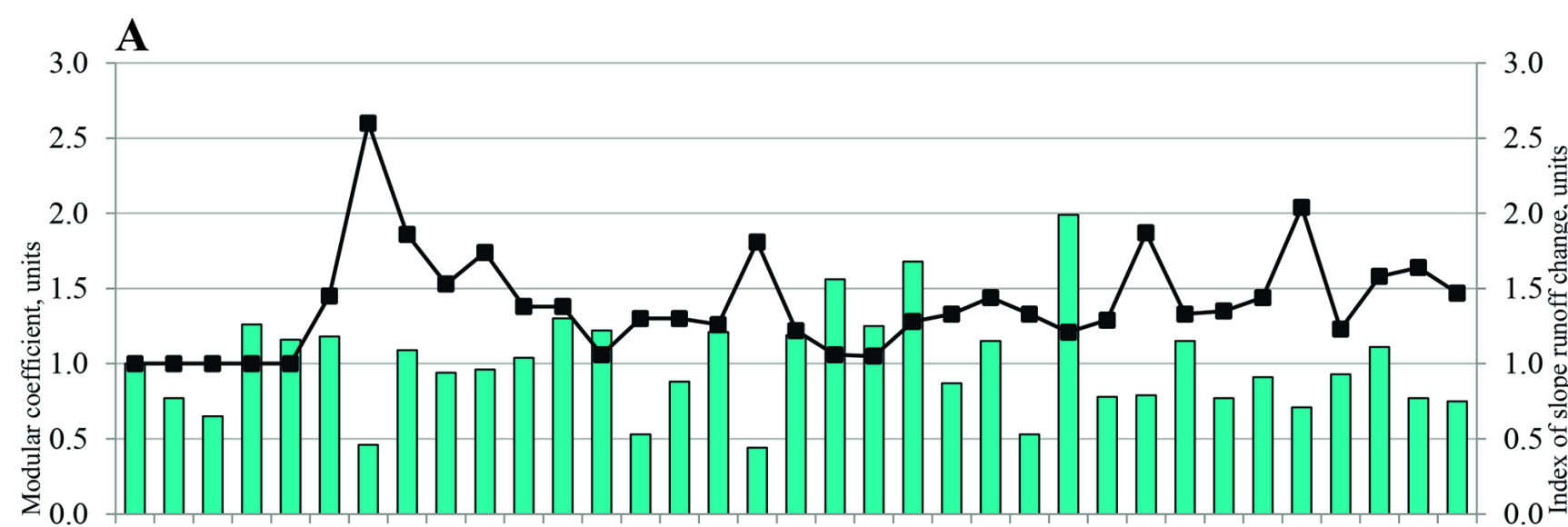

क

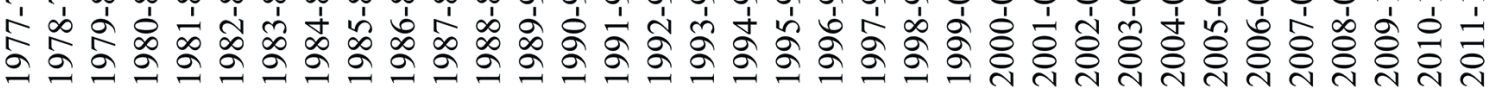
hydrological year

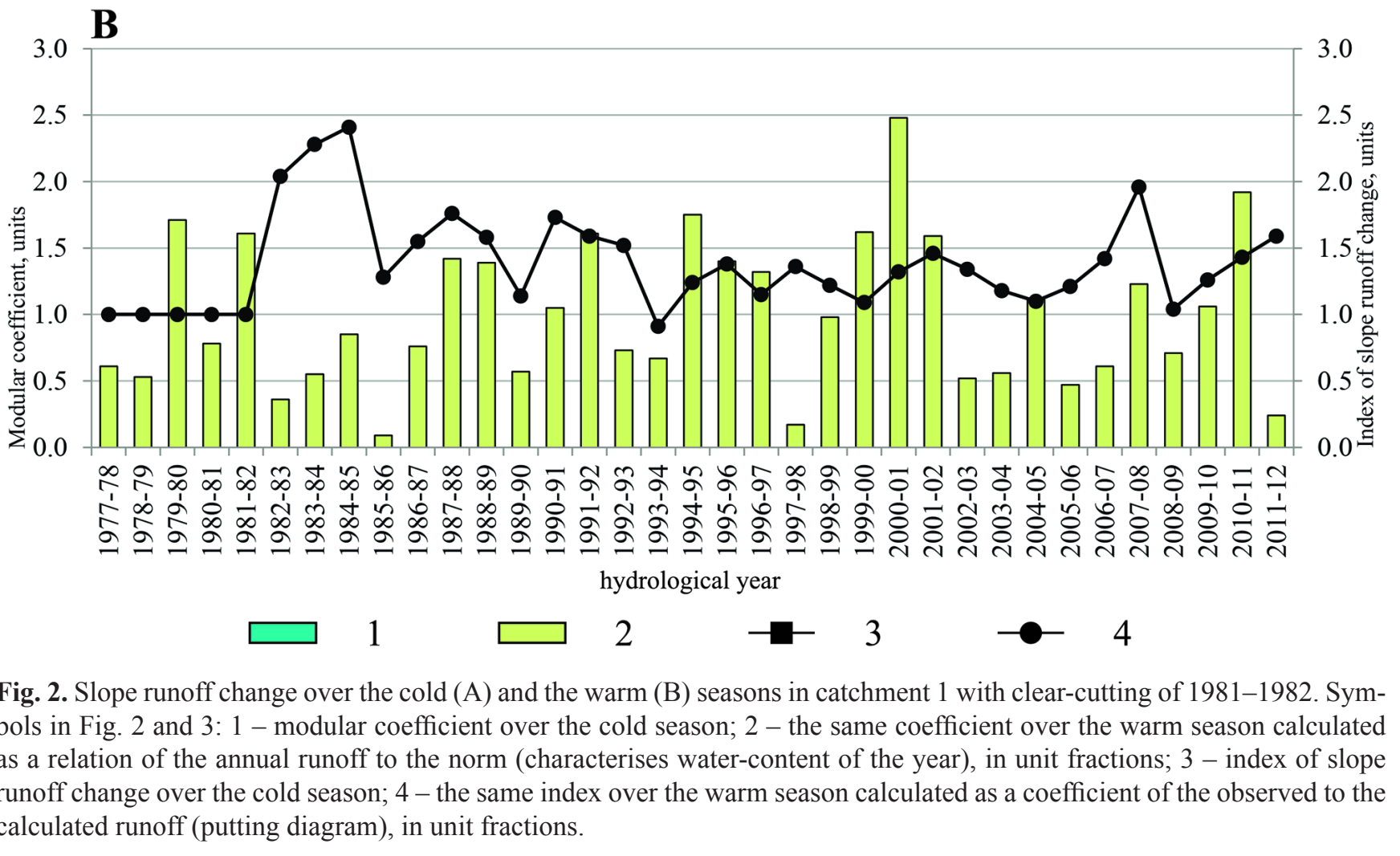
calculated runoff (putting diagram), in unit fractions. 


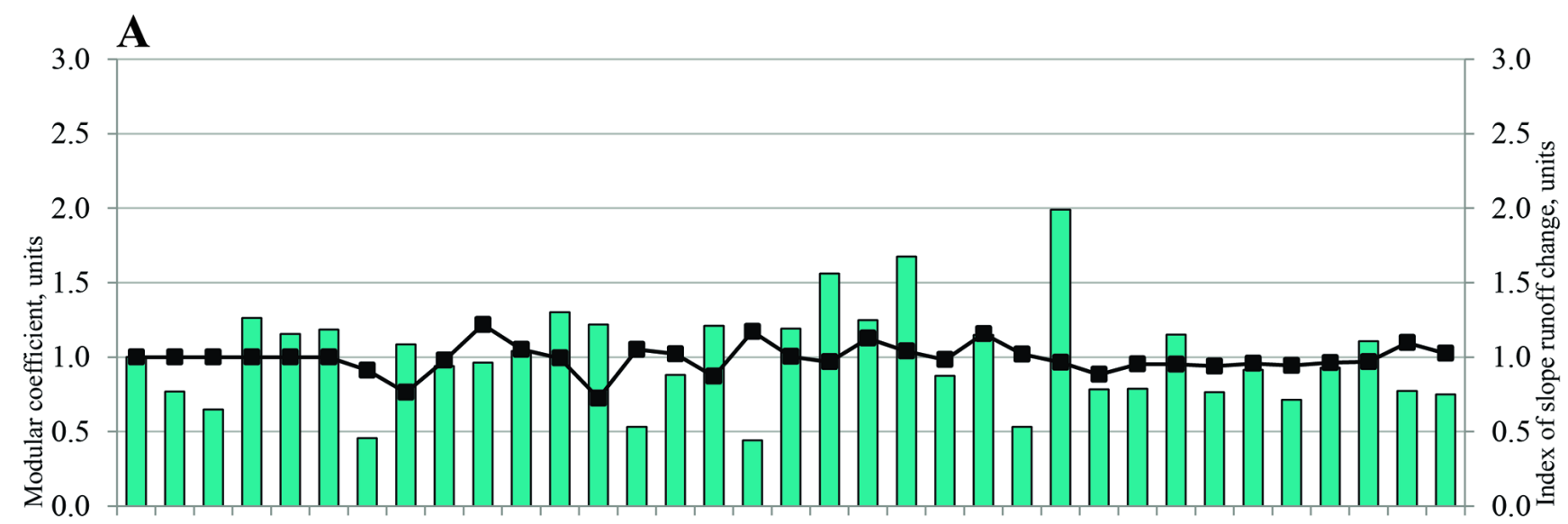

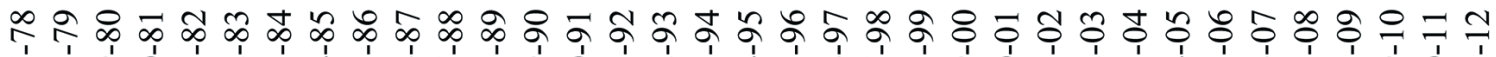

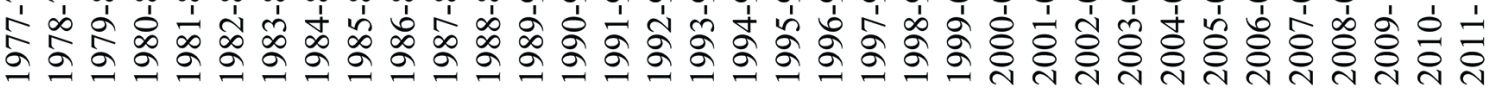
hydrological year

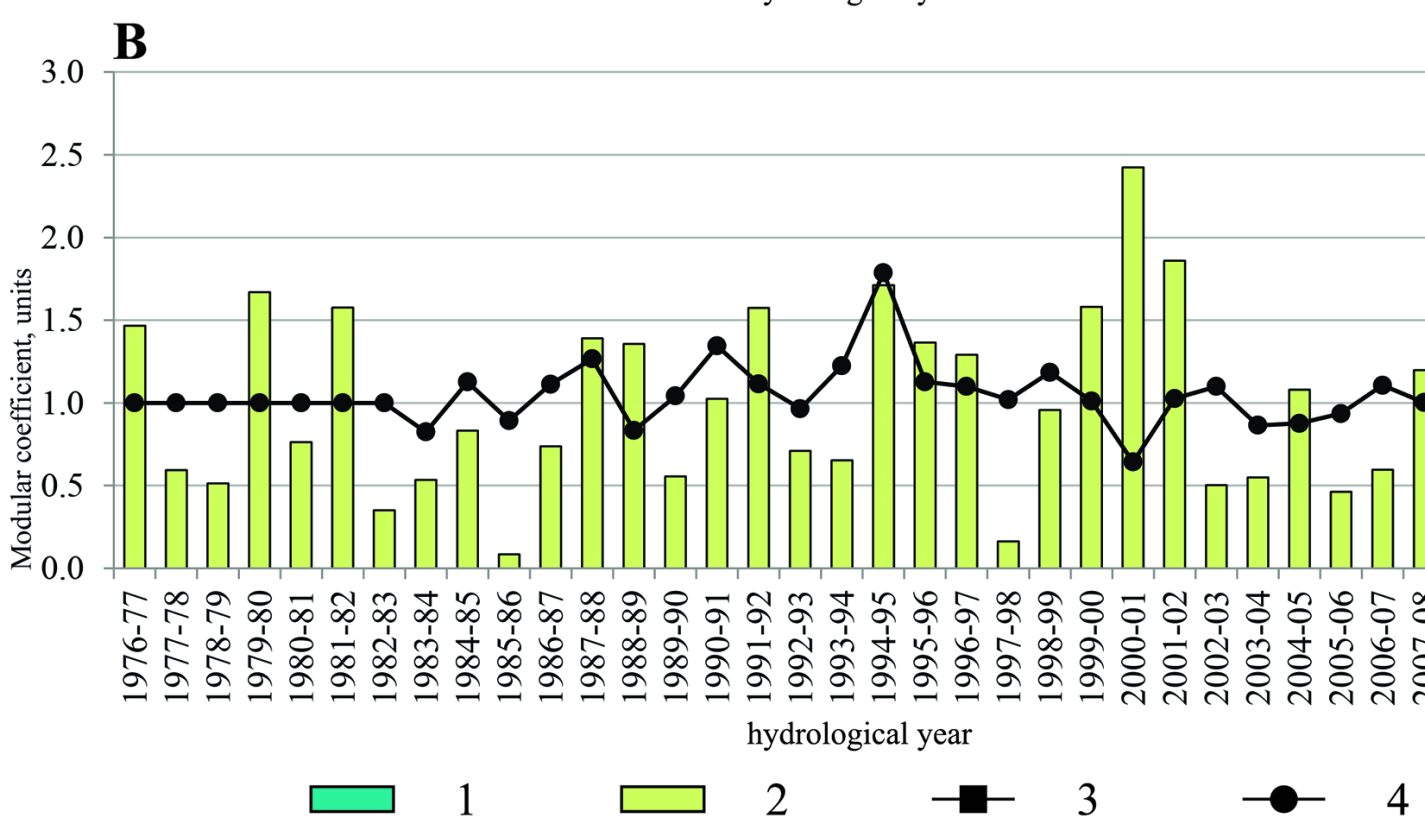

Fig. 3. Slope runoff change over the cold (A) and the warm (B) seasons in catchment 2 with group felling of 1982-1983 and 1988-1989. Symbols: see Fig. 2.

Both in a clear-cutting area with 30-year-old saplings and in a catchment with group felling, indexes of slope runoff change get reduced to 0.9 in some years, and get increased to $1.2-1.3$ in other years, especially during cold seasons, when the regulation of rainfall by a catchment area is minimal and the coefficients of winter floods are close to 0.95 (Fig. 2, 3).

\section{Conclusions}

Long-term studies have found that the water protection role of the oak forests in the Western Caucasus is evident in the continuous influence of forest vegetation on a water balance of the elementary catchments. This influence is manifested through an increased soil supply of rivers and groundwater resources that determines the quality of water and a balance mode of their consumption. The expedition studies of runoff formation in the oak forests zone have shown that soaking conditions are characterised by extreme diversity. On the slopes with frustrated forest stands of secondary origin with closeness of $0.3-0.4$ (which appear in the areas of intensive forest management), runoff coefficients can reach very high numbers $(0.8-0.9)$ at the proportion of a surface runoff up to $90 \%$, i.e. almost all the precipitation is discharged into the main river by a rapid slope runoff, causing catastrophic flooding and an intensive soil erosion on the slopes.

A study of the slope runoff in small catchments in sessile oak formations has found that the conditions for flood control in this area are very unfavourable. The maximum annual runoff modules are 
also very high - in some years they reach 49 1/s per $10,000 \mathrm{~m}^{2}$. The mountain slopes under oak forests in the region cannot handle the water showers by drainage only when their intensity is more than 0.1 $\mathrm{mm} / \mathrm{min}$, and the amount of rainfall is over $30 \mathrm{~mm}$.

Felling significantly affects the components of the water balance of plants. It leads to increases in slope runoff and reduces in a summarised infiltration and evapotranspiration component. It is experimentally proved that the greatest violation of water-regulating functions of Quercus petraea stands occurs when clear-cutting technology with tractor harvesting activities is applied. Under an initially mild capacity of sessile oak formations to regulate water, a negative impact of clear-cutting, in the early years, was manifested in a sharp decrease of the groundwater feeding the rivers (up to zero), due to a sharp increase in the slope runoff.

The situation is worsening due to the climate change observed for the last decade. Thus, in the study area, cases of extreme rainfalls have become more frequent. Under insufficient water regulating functions of oak forests in the study area, it contributes to hazardous hydrological phenomena.

\section{References}

Bitukov N.A. 1981. Guidelines for the study of water-regulating functions of mountain forests. Moscow: All-Russian Research Institute of Silviculture and Mechanisation of Forestry (ARRISMF). 38 p. [In Russian]

Bitukov N.A. 1988. The water balance of watersheds due to logging in the beech forests of the North Caucasus. Lesovedenie 3: 56-65. [In Russian]

Bitukov N.A. 1996. Hydrological role of mountain forests of the Northwest Caucasus. Moscow: Institute of Forest Science RAS (ILAN). 459 p. [In Russian]

Bitukov N.A. 1996. Hydrological role of mountain forests of the Northwest Caucasus. Lesovedenie 4: 39-50. [In Russian]

Bitukov N.A. 2007. Ecology of mountain forests of the Black Sea coast. Sochi: Scientific Research Institute of mountain forestry and forest ecology. 397 p. [In Russian]

Bitukov N.A. 2011. Mountain forest ecosystems dynamics after Sochi Black sea region beech trees chopping. Sochi Journal of Economy 2: 172-178. [In Russian]

Bitukov N.A., Pestereva N.M., Tkachenko Yu.Yu., Shagarov L.M. 2012. Recreation and ecosystem monitoring of protected areas of North Caucasus. Sochi: Sochi State University. 456 p. [In Russian]

Bitukov N.A., Polezhaj P.M., Shagarov L.M. 2011. Sochi national park land system principles aimed at its activity optimisation. Sochi Journal of Economy 3: 256-262. [In Russian]

Bitukov N.A., Shagarov L.M. 2013. Monitoring of Atmospheric Precipitations in Black Sea Coastal Beech For- ests. University News. North-Caucasian region. Natural sciences series 5: 65-67. [In Russian]

Bitukov N.A., Shagarov L.M. 2013. Temperature and Humidity under the Beech Forest Canopy in the Mzymta River Basin. University News. North-Caucasian region. Natural sciences series 1: 67-71. [In Russian]

Dee D.P., Uppala S.M., Simmons A.J., Berrisford P., Poli P., Kobayashi S., Andrae U., Balmaseda M.A., Balsamo G., Bauer P., Bechtold P., Beljaars A.C.M., van de Berg L., Bidlot J., Bormann N., Delsol C., Dragani R., Fuentes M., Geer A.J., Haimberger L., Healy S.B., Hersbach H., Hólm E.V., Isaksen L., Kållberg P., Köhler M., Matricardi M., McNally A.P., Monge-Sanz B.M., Morcrette J.-J., Park B.-K., Peubey C., de Rosnay P., Tavolato C., Thépaut J.-N., Vitart F. 2011. The ERA-Interim reanalysis: Configuration and performance of the data assimilation system. Quarterly Journal of the Royal Meteorological Society 137: 553-597.

Donat M.G., Alexander L.V., Yang H., Durre I., Vose R., Dunn R.J.H., Willett K.M., Aguilar E., Brunet M., Caesar J., Hewitson B., Jack C., Klein Tank A.M.G., Kruger A.C., Marengo J., Peterson T.C., Renom M., Oria Rojas C., Rusticucci M., Salinger J., Elrayah A.S., Sekele S.S., Srivastava A.K., Trewin B., Villarroel C., Vincent L.A., Zhai P., Zhang X., Kitching S. 2013. Updated analyses of temperature and precipitation extreme indices since the beginning of the twentieth century: The HadEX2 dataset. Journal of Geophysical Research: Atmospheres 118: 2098-2118.

Groisman P.Ya., Knight R.W., Easterling D.R., Karl T.R., Hegerl G.C., Razuvaev V.N. 2005. Trends in intense precipitation in the climate record. Journal of Climate 18: 1326-1350.

Herring S.C., Hoerling M.P., Peterson T.C., Stott P.A. 2014. Explaining extreme events of 2013 from a climate perspective. Special Supplement to the Bulletin of the American Meteorological Society 95 (9): 1-96.

Kotlyakov V.M., Desinov L.V., Dolgov S.V., Koronkevich N.I., Likhacheva E.A., Makkaveev A.N., Medvedev A.A., Rudakov V.A. 2013. Flooding of July 6-7, 2012 , in the town of Krymsk. Regional Research of Russia 3: 32-39.

Koval I.P., Bitukov N.A. 1972. Quantification of water regulating role of mountain forests of the Black Sea coast. Lesovedenie 1: 3-11. [In Russian]

Koval I.P., Bitukov N.A. 2001. Ecological basis of forest use, mountain catchments (for example, the North Caucasus). Krasnodar: Kuban textbook. 480 p. [In Russian]

Koval I.P., Bitukov N.A., Shevtsov B.P. 2012. Ecological bases of Mountain Forestry. Sochi: Scientific Research Institute of mountain forestry and forest ecology. 545 p. [In Russian]

Meredith E.P., Semenov V.A., Maraun D., Park W., Chernokulsky A.V. 2015. Crucial role of Black Sea warming in amplifying the 2012 Krymsk precipitation extreme. Nature Geosciences 8: 615-619.

Min S.K., Zhang X., Zwiers F.W., Hegerl G.C. 2011. Human contribution to more intense precipitation extremes. Nature 470: 378-381. 
Pall P., Aina T., Stone D.A., Stott P.A., Nozawa T., Hiberts A.G., Lohmann D., Allen M.R. 2011. Anthropogenic greenhouse gas contribution to flood risk in England and Wales in autumn 2000. Nature 470: 382-385.

Pestereva N.M., Popova N.Y., Shagarov L.M. 2012. Modern climate change and mountain skiing tourism: the Alps and the Caucasus. European Researcher 9-3 (30): 1602-1617.

Polezhaj P.M. 2011. Oak forests of the North Caucasus. Sochi: Scientific Research Institute of mountain forestry and forest ecology. 250 p. [In Russian]

Seneviratne S.I., Nicholls N., Easterling D., Goodess C.M., Kanae S., Kossin J., Luo Y., Marengo J., McInnes K., Rahimi M., Reichstein M., Sorteberg A., Vera C., Zhang X. 2012. Changes in Climate Extremes and their Impacts on the Natural Physical Environment. In: C.B. Field, V. Barros, T.F. Stocker, D. Qin, D.J. Dokken,
K.L. Ebi, M.D. Mastrandrea, K.J. Mach, G.-K. Plattner, S.K. Allen, M. Tignor, P.M. Midgley (eds.): Managing the Risks of Extreme Events and Disasters to Advance Climate Change Adaptation. Cambridge: IPCC, Cambridge University Press. P. 109-230.

Shagarov L.M. 2012. The Ecological Monitoring of Montane Forest Ecosystems. University News. North-Caucasian region. Natural sciences series 5: 91-94. [In Russian]

Shagarov L.M. 2013. Geoecological features and rational use of beech and oak forests of the Black Sea coast. Rostov-on-Don: Southern Federal University. 200 p. [In Russian]

Zhang X., Zwiers F.W., Hegerl G.C., Lambert F.H., Gillett N.P., Solomon S., Stott P.A., Nozawa T. 2007. Detection of human influence on twentieth-century precipitation trends. Nature 448: 461-465.

\title{
НАРУШЕНИЕ ВОДООХРАННОЙ ФУНКЦИИ ГОРНЫХ ДУБРАВ ЗАПАДНОГО КАВКАЗА В РЕЗУЛЬТАТЕ РУБОК ГЛАВНОГО ПОЛЬЗОВАНИЯ
}

\author{
Н. А. Битюков ${ }^{1}$, Л. М. Шагаров ${ }^{2}$ \\ ${ }^{1}$ Сочинский национальный парк, Россия \\ e-mail:nikbit@mail.ru \\ ${ }^{2}$ Природный орнитологический парк в Имеретинской низменности, Россия \\ e-mail:lev049@mail.ru
}

\begin{abstract}
Статья посвящена анализу влияния рубок главного пользования на нарушение водоохранной функции горных дубрав Западного Кавказа. В основу исследования легли результаты многолетнего мониторинга ручьевого стока на водосборах с опытными рубками лесогидрологического стационара «Горский» (Туапсинский район, Краснодарский край). Установлено, что в течение 28-летнего периода после проведения опытных рубок стабилизация условий формирования стока так и не наступила. Наибольшее воздействие на сток в дубравах оказывают сплошнолесосечные рубки с тракторной технологией лесозаготовок. За 30-летний период после сплошнолесосечной рубки ручьевой сток увеличился в среднем в 1.46 раза, а максимальное увеличение (в 2.5 раза) наблюдалось в первые два года после рубки. На площадях с котловинной рубкой режим стока за такой же период в целом аналогичен показателям контрольного водосбора.
\end{abstract}

Ключевые слова: Quercus petraea, горные леса, опытные рубки, паводки, склоновый сток, Черноморское побережье. 